\title{
Screening an Effective Aerobic Denitrification Strain and its Performance in MBR
}

\author{
Jifeng Guo*, Ping Guo, Simeng Li, Xiaojie Li, \\ Chongli Luo, Hui Wang, Qian Jiang \\ School of Environmental Science and Engineering, Key Laboratory of Subsurface Hydrology \\ and Ecology in Arid Areas of Education Ministry, \\ Chang'an University, Xi'an, 710064, P.R. China
}

Received: 6 June 2016

Accepted: 4 December 2016

\begin{abstract}
A highly effective aerobic denitrification strain was screened from the municipal activated sludge and its gene sequence was obtained from DNA extraction and amplified by the polymerase chain reaction (PCR) amplification. Based on the result, the strain was preliminarily identified to be Pseudomonas by way of comparison with the National Centre for Biotechnology Information (NCBI) Genbank. In order to get more knowledge of the aerobic denitrification strain and its application in wastewater treatment, the strain was added into the membrane bioreactor (MBR) to construct a denitrification MBR (dMBR) for municipal wastewater treatment due to its high denitrification ability. The experiment results showed that nitrogen removal efficiency was as high as $80 \%$ in dMBR and nitrogen removal efficiency was $50 \%$ in the control MBR (cMBR), which indicated that aerobic denitrification in the MBR tank played a main role in removing the nitrogen under aerobic conditions. The best strain dosage was $20-30 \%$ in the total activated sludge. The dMBR also had a better membrane fouling resistant effect than cMBR. As a result, the dMBR could be an effective method for nitrogen removal of the wastewater treatment.
\end{abstract}

Keywords: screening, aerobic denitrification strain, membrane bioreactor (MBR), trans-membrane pressure (TMP)

\section{Introduction}

Due to the large amount of industrial wastewater discharge and long-term excessive use of agricultural fertilizers, nitrate water pollution is serious. Nitrate can be transformed into one of the three major carcinogenic nitrosamines, which are greatly harmful to human health. Nitrogen is also a major substance that causes

*e-mail: guojifeng@chd.edu.cn eutrophication [1-3]. In 1980s, researchers found aerobic denitrification strains from the effluent of the denitrification treatment system, and they isolated aerobic denitrification strains such as Paracoccus pantotropha, Pseudomonas sp., and Alcaligenes faecalis, etc. [4-5]. Then more and more researchers investigated the aerobic denitrification strains [6-8]. However, the studies had been limited in strain screening and their culture conditions. It was seldom that the strains were put into the bioreactors for treating nitrogen wastewater.

Membrane bioreactors (MBR) are activated sludge processes where the secondary settling tank is substituted 
by a membrane filtration unit. The main advantages lie in the high sludge concentration in combination with an excellent effluent quality [9-10].

However, one disadvantage is that the MBR has low denitrification because continuous aeration must be performed to delay membrane fouling [11]. Despite the existing simultaneous nitrification and denitrification (SND) phenomena in MBR, the condition in the MLSS must be as high as 20 30 g/L [12] and the SND is also limited. At the same time, the high MLSS concentration can result in serious membrane fouling. So far for most MBR designs, the traditional nitrogen removal method (adding anoxic (AN) tank) is adopted because of its popularity in the treatment. For example, the predenitrification stage [13], the post-denitrification stage [14], and the sequencing batch membrane bioreactors [15] are all used to remove nitrogen. These MBRs technologies undoubtedly add to the investment.

An aerobic denitrification strain can remove nitrogen under aerobic conditions. If these strains were used in MBR [16], the above denitrification stage could be omitted to save more investments. But there was competition for several kinds of aerobic denitrification strains in the longrunning of MBR, especially in the absence of a carbon source. And the aerobic denitrification strains might be degraded and lose their role of denitrification. So it is important that screening the aerobic denitrification strain could adapt to MBR's running conditions (the absence of a carbon source).

To get more knowledge of aerobic denitrification strains and its application in municipal wastewater, a kind of aerobic denitrification strain was screened from a local wastewater treatment plant (A2/O process). The strain was applied in MBR to study the bioreactor's performance of nitrogen removal, which is expected to be an effective way to solve the environmental issue of nitrogen removal.

\section{Material and Methods}

\section{Strain Screening}

\section{Microorganism's Origin}

The sample came from the activated sludge in the aeration tank of the Fourth Municipal Wastewater Treatment Plant (MWTP) in Xi'an city, China.

\section{Culture Medium}

Culture mediums were prepared according to [17]. a) Enriched culture medium (FM culture medium)
Enriched culture medium was composed of beef extract $1.0 \mathrm{~g} / \mathrm{L}$, peptone $5.0 \mathrm{~g} / \mathrm{L}$, and $\mathrm{KNO}_{3} 1.0 \mathrm{~g} / \mathrm{L}$.

b) Selective culture medium (DM culture medium)

Selective culture medium was composed of $\mathrm{Na}_{2} \mathrm{HPO}_{4} \cdot 7 \mathrm{H}_{2} \mathrm{O} 7.9 \mathrm{~g} / \mathrm{L}, \mathrm{KH}_{2} \mathrm{PO}_{4} 1.5 \mathrm{~g} / \mathrm{L}, \mathrm{NH}_{4} \mathrm{Cl} 0.3 \mathrm{~g} / \mathrm{L}$, $\mathrm{MgSO}_{4} \cdot 7 \mathrm{H}_{2} \mathrm{O} 0.1 \mathrm{~g} / \mathrm{L}$, sodium succinate $4.7 \mathrm{~g} / \mathrm{L}, \mathrm{KNO}_{3}$ $2.0 \mathrm{~g} / \mathrm{L}, \mathrm{NaNO}_{2} 1.0 \mathrm{~g} / \mathrm{L}$, and $\mathrm{pH}$ 7-7.5.

\section{Domestication and Pure Strain Separation}

The sample was inoculated in FM culture medium, then was cultured on the rotary shaker with intermittent aeration at $25^{\circ} \mathrm{C}$ and $160 \mathrm{r} / \mathrm{min}$ for $5 \mathrm{~d}$. Forty-eight types of strains were screened. Then these strains were inoculated in DM culture medium at $25^{\circ} \mathrm{C}$ and $160 \mathrm{r} / \mathrm{min}$ for $40 \mathrm{~h}$. After that, measuring the total nitrogen (TN) concentrations in the bacterium suspension to select the highly effective strains by inspecting the bacterium suspension's TN removal ratio was above 50\%.

\section{Strains Rescreening}

The obtained strains were rescreened with simulated municipal wastewater (Table 1) to get better denitrification performance strains. The strains were inoculated in the above medium, and then were cultured on the rotary shaker with intermittent aeration at $25^{\circ} \mathrm{C}$ and $160 \mathrm{r} / \mathrm{min}$ for $5 \mathrm{~d}$.

The better denitrification performance strains whose TN removal ratios were above $90 \%$ could be chosen.

\section{Enhanced Strains Rescreening}

The obtained strains were rescreened using supernatant liquor from an MBR treating simulated municipal wastewater (almost without ammonia, but nitrate and nitrite only, Table 2) to investigate the denitrification performance in order to enable the strains to get better adaption in the actual operation of the sewage treatment process at $25^{\circ} \mathrm{C}$ and $\mathrm{pH} 7$, especially in the conditions of EPS and SMP as the carbon source.

Then the strain of the best nitrogen removal efficiency will be chosen.

\section{Strains Identification}

DNA of the screened strains were extracted and amplified by polymerase chain reaction (PCR) amplification method [18], then the samples were sent to Shanghai Sangon Biological Engineering Technology \& Services Co., Ltd. for gene sequenceing. The bacterial morphology was observed by scanning electron microscopy (SEM).

Table 1. Simulated municipal wastewater.

\begin{tabular}{|c|c|c|c|c|c|c|}
\hline Item & $\begin{array}{c}\text { Total Nitrogen } \\
(\mathrm{mg} / \mathrm{L})\end{array}$ & $\begin{array}{c}\text { Ammonia } \\
(\mathrm{mg} / \mathrm{L})\end{array}$ & $\begin{array}{c}\text { Nitrate } \\
(\mathrm{mg} / \mathrm{L})\end{array}$ & $\begin{array}{c}\text { Nitrite } \\
(\mathrm{mg} / \mathrm{L})\end{array}$ & $\begin{array}{c}\mathrm{COD}_{\mathrm{Cr}} \\
(\mathrm{mg} / \mathrm{L})\end{array}$ & $\mathrm{pH}$ \\
\hline Influent & $45-50$ & $20-45$ & $2-20$ & $0-3$ & 270 & $6.9-7.2$. \\
\hline
\end{tabular}


Table 2. Simulated municipal wastewater (without ammonia, but nitrate and nitrite only).

\begin{tabular}{|c|c|c|c|c|c|c|}
\hline Item & $\begin{array}{c}\text { Total Nitrogen } \\
(\mathrm{mg} / \mathrm{L})\end{array}$ & $\begin{array}{c}\text { Ammonia } \\
(\mathrm{mg} / \mathrm{L})\end{array}$ & $\begin{array}{c}\text { Nitrate } \\
(\mathrm{mg} / \mathrm{L})\end{array}$ & $\begin{array}{c}\text { Nitrite } \\
(\mathrm{mg} / \mathrm{L})\end{array}$ & $\begin{array}{c}\mathrm{COD}_{\mathrm{Cr}} \\
(\mathrm{mg} / \mathrm{L})\end{array}$ & $\begin{array}{c}\mathrm{pH} \\
\text { Influent }\end{array}$ \\
\hline
\end{tabular}

a) DNA extraction:

Several single colonies from the culture medium were picked up with inoculating loop and placed into $200 \mathrm{~mL}$ Eppendorf pipes (with $30 \mu \mathrm{L}$ sterile doubledistilled water), then heated at $94^{\circ} \mathrm{C}$ in the water bath for 2-4 minutes so the cell wall would be broken and the inner DNA would come out. Then the liquid could be as a DNA template and ready to be amplified by PCR.

b) PCR amplification primer and procedure:

Sense primer P1: 27F (5'-AGAGTTTGATCCTGGCTCAG-3'), anti-sense primer P2: 1492R (5'-TACGGCTACCTTGTTACGACTT-3'). The above primers were synthesized by Shanghai Invitrogen Biological Engineering Technology \& Services Co., Ltd., China.

PCR amplification procedure: the DNA template was pre-denatured at $94^{\circ} \mathrm{C}$ for $4 \mathrm{~min}, 30$ cycles (denatured $45 \mathrm{~s}$ at $94^{\circ} \mathrm{C}$, annealed $30 \mathrm{~s}$ at $60^{\circ} \mathrm{C}$, extented $90 \mathrm{~s}$ at $72^{\circ} \mathrm{C}$ ), and finally extented $12 \mathrm{~min}$ at $72^{\circ} \mathrm{C}$. The total volumes of PCR reaction system were $50 \mu \mathrm{L}$ (sterile double-distilled water $40 \mu \mathrm{L}, 10 \times \mathrm{PCR}$ reaction buffer $5 \mu \mathrm{L}, 4 \times \mathrm{dNTP}$ solution 1 $\mu \mathrm{L}, 10 \mathrm{mmol} / \mathrm{L}$ P1 $1 \mu \mathrm{L}, \mathrm{P} 21 \mu \mathrm{L}$, taq dna polymerase $1 \mathrm{U}$, and DNA template $2 \mu \mathrm{L}$ ).

DNA and PCR products were detected by $0.8 \%$ and $1 \%$ agarose gel electrophoresis, respectively (about $30 \mathrm{~min}, 150 \mathrm{~V}$, observed under ultraviolet lamp), then stored at $-20^{\circ} \mathrm{C}$. FQ DL2000 DNA Marker was synthesized by Shanghai Biocolors Biological Engineering Technology \& Services Co., Ltd.

The DNA sequencing was intercompared by the National Centre for Biotechnology Information (NCBI) Genbank of U.S.A.

\section{Experiment Setup}

Two MBRs were used in the experiment: one was only added with the activated sludge from the Fourth MWTP, which was named controlled MBR (cMBR); another was added with aerobic denitrification strains and the activated

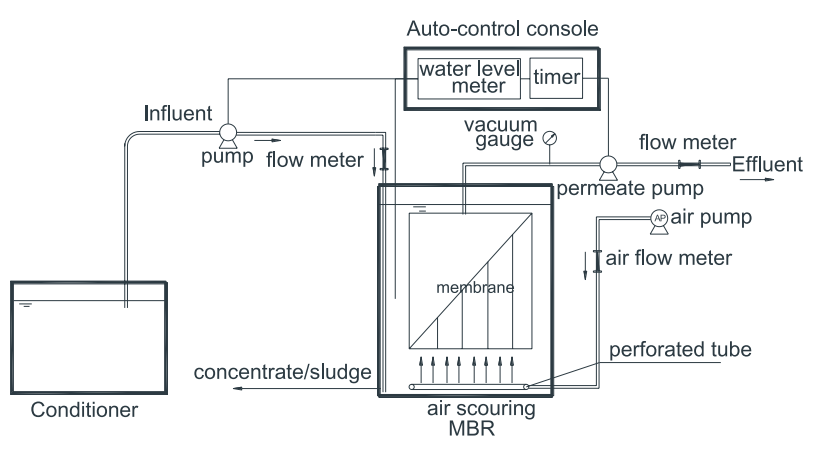

Fig. 1. Membrane bioreactor (MBR) sketch. sludge, which was named denitrification MBR (dMBR). The MBRs used to treat the municipal wastewater had a total volume capacity of $1.0 \mathrm{~L}$ (Fig. 1).

They were equipped with hollow-fiber ultra filtration (UF) membrane modules made of PVDF (Hangzhou Qiushi Membrane Technology Co., Ltd) with a total surface area of $0.015 \mathrm{~m}^{2}$ and a nominal pore size of $0.01 \mu \mathrm{m}$. The flux of the membrane was $12 \mathrm{~L} / \mathrm{m}^{2} \cdot \mathrm{h}$. Air was supplied through an axial perforated tube below the membrane modules to supply oxygen demanded by the microorganisms and induce a cross-flow velocity along the membrane surface. The wastewater from the storage tank was supplied by an influent pump into the bioreactor. The HRT of the MBR was 6 hours. In the whole operation, the activated sludge was not discharged. The quality of the raw wastewater is listed in Table 1. The membrane-filtered effluent was obtained by suction using a pump connected to the modules. The effluent flow rate and trans-membrane pressure (TMP) were monitored by a water meter and a vacuum gauge, respectively.

\section{Analytical Items and Methods}

Wastewater parameters, including $\mathrm{COD}_{\mathrm{Cr}}, \mathrm{TN}$, and $\mathrm{NH}_{4}{ }^{+} \mathrm{N}$, were analyzed according to the Chinese NEPA standard methods (1997) [19].

\section{Results and Discussion}

\section{Strains Screening and Identification}

According to the strains rescreening procedure, two kinds of aerobic denitrification strains whose TN removal efficiency were both over $90 \%$ were screened: Strain 1 and Strain 2.

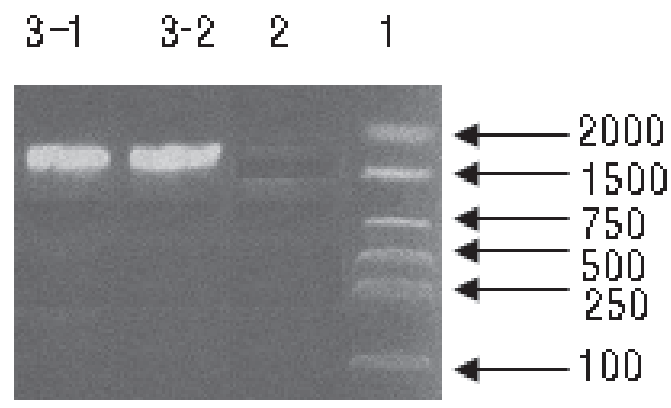

Fig. 2. PCR amplification.

1: Marker, 2: Negative Control, 3-1: PCR product of Strain 1, 3-2: PCR product of Strain 2 


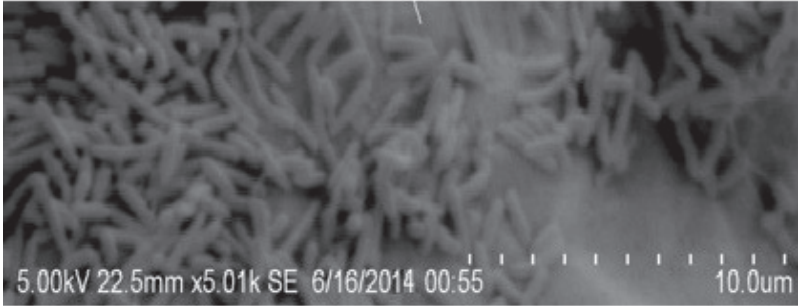

a) $\operatorname{strain} 1$

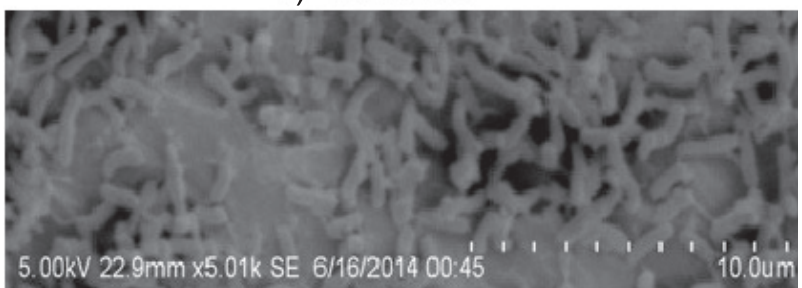

b) strain 2

Fig. 3. SEM photos of strains.

The extracted DNA was PCR-amplified by amplified primers. Observed by agarose gel electrophoresis, the amplified fragments were both about 1,500 bp (shown in Fig. 2), and were proved to be target fragments without tails. The results of PCR amplification were satisfied.

\section{Characteristics of the Strains}

Both strain cells had short-rod shapes and were gram negative. And their colonies were white with circle points in the middle and smooth edges. The strains' shapes are shown in Fig. 3 (SEM photos).

\section{Enhanced Strain Rescreening}

The two kinds of strains (1 and 2) that had good denitrification performance were selected by the enhanced rescreening method. The results showed that the TN removal efficiency of strains 1 and 2 were $50 \%$ and $10 \%$, respectively. Then strain 1 was selected as the experimental strain.

The gene sequences from the bands were sequenced by Sagon Company (Shanghai, China) and were compared with the NCBI Genbank. And the strains were preliminarily identified to be Pseudomonas, whose coverage was $98.9 \%$ with the target sequence (Table 3). Fig. 4 showed
Table 3. Sequence length and closest phylogenetic affiliation of two strains.

\begin{tabular}{|c|c|c|c|}
\hline \multirow{2}{*}{ Strains } & \multirow{2}{*}{$\begin{array}{c}\text { Sequence } \\
\text { length }\end{array}$} & \multicolumn{2}{|c|}{ Phylogenetic relationship } \\
\cline { 3 - 4 } & & Species & Similarity \\
\hline 1 & 190 & Pseudomonas $\mathrm{sp}$. & $193 / 195(98.9 \%)$ \\
\hline 2 & 168 & paracoccus $\mathrm{sp}$. & $209 / 219(95.4 \%)$ \\
\hline
\end{tabular}

the phylogenetic tree of the denitrification strain, which was constructed using molecular evolutionary genetics analysis (MEGA 6) software [20] according to the neighbor-joining method [21].

It was confirmed that Pseudomonas bacteria genera was common denitrifying bacteria [22]. As shown in Fig. 4, Pseudomonas sp. strain W10 16S ribosomal RNA gene partial sequence, Uncultured Pseudomonas sp. $16 \mathrm{~S}$ rRNA gene clone 65p38, Uncultured Pseudomonas sp. clone 361 16S ribosomal RNA gene partial sequence, and Pseudomonas sp. Isoamylase gene complete cds were relatively close in genetic distances. These four kinds of Pseudomonas sp. strains had different genetic relationships from Pseudomonas fluorescens PfO-1 and Pseudomonas sp. 2 - haloalkanoic acid dehalogenase genes. The latter two kinds of strains belonged to the same branch, but their similarity was smaller.

\section{Species-Rich}

A $1 \mathrm{~mL}$ sample was inoculated in enriched culture medium (FM) contained in a $1,000 \mathrm{~mL}$ conical flask, then was cultured on a rotary shaker at $25^{\circ} \mathrm{C}$ and $160 \mathrm{r} / \mathrm{min}$ for $5 \mathrm{~d}$. Then all the bacteria suspensions were filtered by filter paper. The intercepted strains were stored for use. After species-rich, the net weight of strains in $1,000 \mathrm{~mL}$ conical flasks was $0.5 \mathrm{~g}$.

\section{Dosage of Strain}

Activated sludge MLSS in the reactor is $8 \mathrm{~g} / \mathrm{L}$. In order to maintain the same amount of sludge amount, some activated sludge in the dMBR should be discarded. For example, for the dosage of $10 \%$ of the bacteria in the dMBR, two $1,000 \mathrm{ml}$ conical flasks with aerobic denitrification strains were needed, while removing $1 \mathrm{~g}$ activated sludge from the dMBR. The procedure is: $1 \mathrm{~L}$ of activated sludge in the reactor was centrifuged at

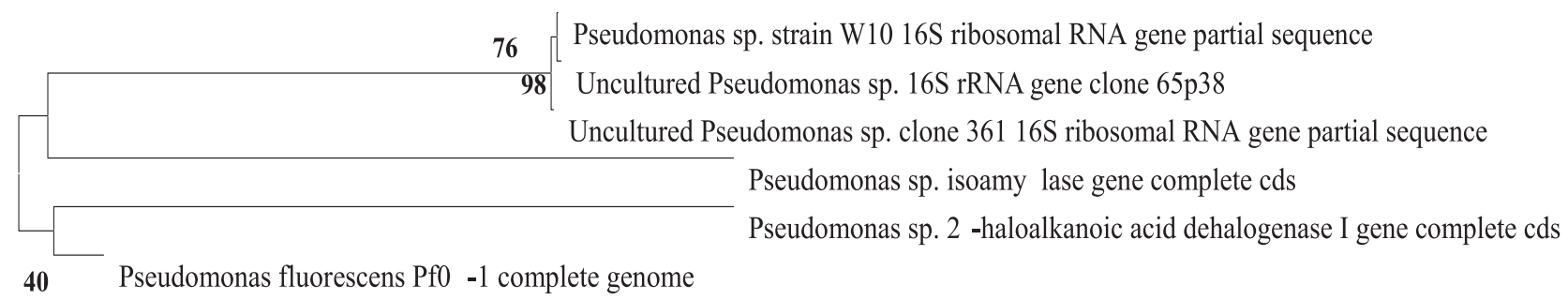

Fig. 4. The phylogenetic tree of the strain. 
3,000 rpm for 10 minutes, and $200 \mathrm{~mL}$ supernatant was discarded to become $800 \mathrm{~mL}$ volume. A $1 \mathrm{~L}$ conical flask with species was also centrifuged at 3,000 rpm for 10 minutes, and $900 \mathrm{~mL}$ supernatant was discarded to become $100 \mathrm{~mL}$ volume. Two bottles of this $100 \mathrm{~mL}$ concentrated strain and $800 \mathrm{~mL}$ of concentrated activated sludge were mixed, and $10 \%$ of the strain dosage was obtained.

\section{Performance of two MBRs}

It must be asserted that the influent was well buffered and accordingly the reactor $\mathrm{pH}$ throughout phases of operation was between 6.8 and 7.4. The ammonia stripping could be neglected because ammonia in water with such a range of $\mathrm{pH}$ existed mostly as ammonium ions at ambient temperature. Of course assimilation was responsible for $25 \sim 30 \%$ of the nitrogen loss in the biological wastewater treatment process [23]. The endogenous respiration could also compensate a lot for the nitrogen loss in the MBR with long SRT 20 40 d [24]. Therefore, the dissimilation by bacteria mainly contributed to nitrogen loss in the ordinary MBR and traditional nitrogen removal (TNR), or SND would take the main contribution in nitrogen removal.

In fact, two parallel MBRs were operated on under the same conditions (Intermittent filtration: $12 \mathrm{~min}$ filtration and 3-min pause; DO is $3-4 \mathrm{mg} / \mathrm{L}$; MLSS is 8 $\mathrm{g} / \mathrm{L})$ to investigate the relationship of dosage of strain and pollution removal efficiency. $10 \%, 20 \%, 30 \%, 40 \%$, and $50 \%$ dosage of strains were added to the dMBR, respectively, while reducing the amount of activated sludge to enable the total MLSS concentration in dMBR of $8 \mathrm{~g} / \mathrm{L}$. Runtime of the two MBRs was 10 days after every dosing to investigate the removal efficiency of the pollutants - especially nitrogen removal efficiency.

$$
C O D_{C r} \text { Removal }
$$

As can be seen in Fig. 5, $\mathrm{COD}_{\mathrm{Cr}}$ removal was significant in the two reactors. There was no great influence on the early removal of $\mathrm{COD}_{\mathrm{Cr}}$ due to the MBR's characteristics of the high sludge concentration. Of course, the sludge was taken from the municipal wastewater treatment plant aeration tank, which could be well adapted to the simulated municipal sewage.

In the whole stage, the $\mathrm{COD}_{\mathrm{Cr}}$ concentration of effluent fluctuated with the influent and was relatively stable. Then at the later of every stage, activated sludge in cMBR became mature and the EPS in the bioreactor was produced more and more, so the $\mathrm{COD}_{\mathrm{Cr}}$ of supernatant liquor rose gradually (Fig. 5a) [25]. But the $\mathrm{COD}_{\mathrm{Cr}}$ concentration of effluent was still steady due to membrane interception (Fig. 5b) [26]. At the same time, dMBR showed slightly different $\mathrm{COD}_{\mathrm{Cr}}$ concentrations in supernatant liquor from the cMBR, that is the dMBR's supernatant liquor $\mathrm{COD}_{\mathrm{Cr}}$ concentration was reduced gradually, and the $\mathrm{COD}_{\mathrm{Cr}}$ removal efficiency was $83 \%$ when the $\mathrm{COD}_{\mathrm{Cr}}$ concentration of influent fluctuated at $270 \mathrm{mg} / \mathrm{L}$. The aerobic denitrification bacteria strain
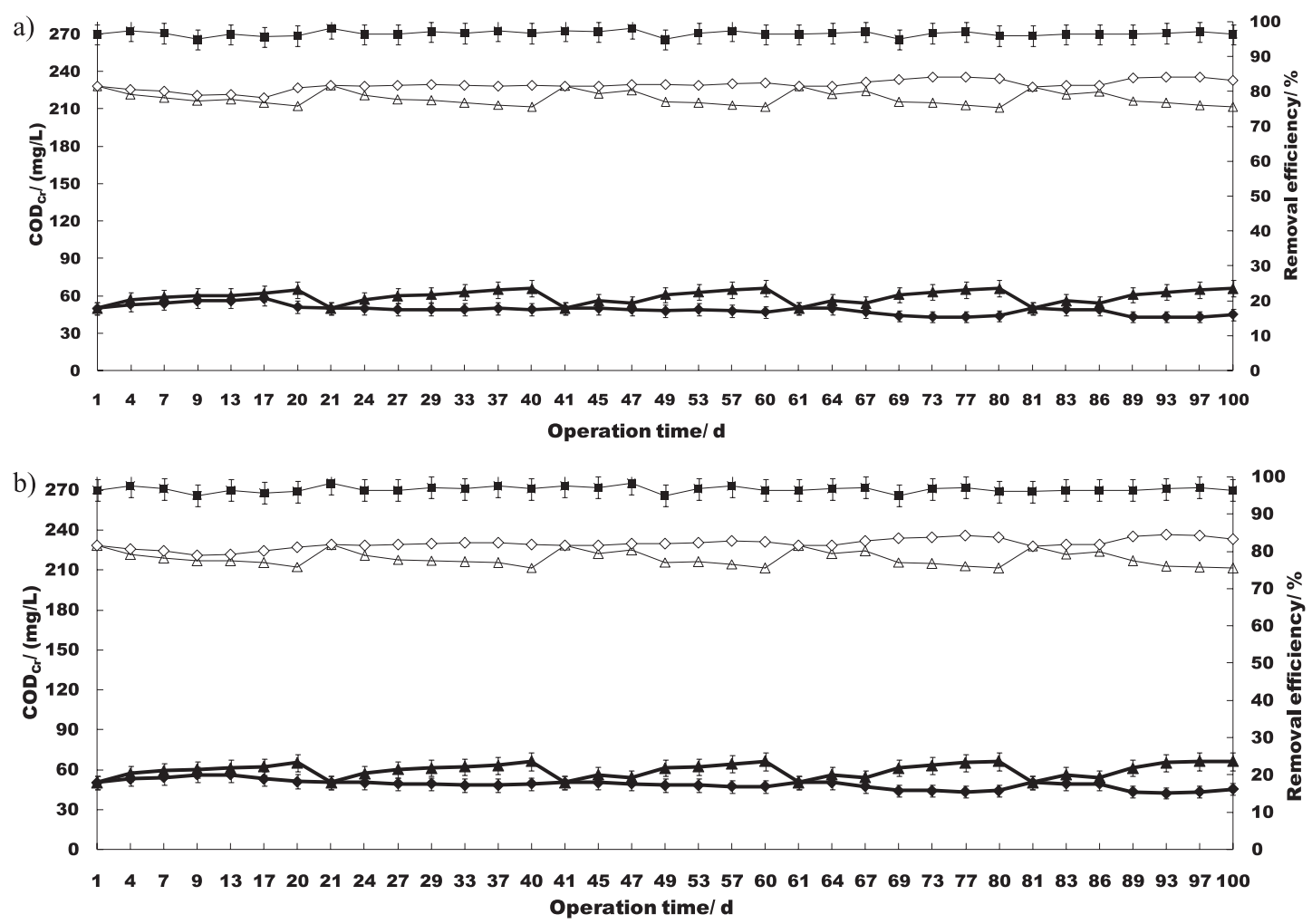

Fig. 5. Variations of $\mathrm{COD}_{\mathrm{Cr}}$ removal of the MBRs. a) Supernatant COD variations of two MBRs, b) Effluent COD variations of two MBRs. 


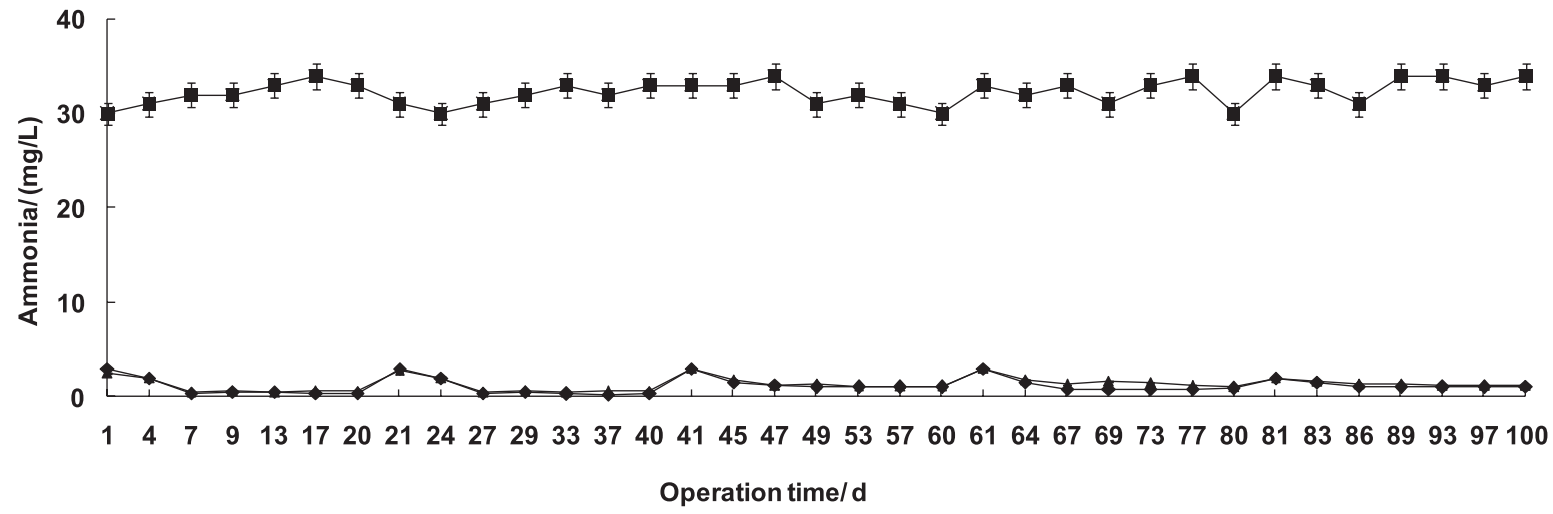

-Influent $\bullet \mathrm{dMBR}$ effluent $\triangle \mathrm{c}$ MBR effluent

Fig. 6. Variations of ammonia removal.

1 in dMBR could adapt to the situation of lacking carbon source and take the $\mathrm{COD}_{\mathrm{Cr}}$ in the supernatant as foodstuff to go on denitrification. So in spite of the whole sludge being in the respiration phase [27], there still was $\mathrm{COD}_{\mathrm{Cr}}$ consumption in the dMBR supernatant.

\section{Ammonia Removal}

As shown in Fig. 6, ammonia removal was high in both of the MBRs, which indicated that ammoniaoxidizing bacteria played a role in removing the ammonia. The ammonia-oxidizing bacteria and nitrobacteria of the activated sludge were intercepted in the activated sludge system by membrane, and the $\mathrm{NH}_{4}^{+}-\mathrm{N}$ removal ratio was over $99 \%$. The advantage of MBR, providing better retention of slow-growing microorganisms (like nitrobacteria) [28], enhanced $\mathrm{NH}_{4}^{+}-\mathrm{N}$ removal.

\section{TN Removal}

As shown in Fig. 7, TN removal in the dMBR was more satisfying than that in the cMBRs. No doubt, the nitrogen removal benefited from the strain in the MBR tank. In the cMBR, it was not a similar experience in ammonia removal, indicating that the denitrification bacteria did not have the function to make the ammonia converted to nitrate. The reason was that there was not an anoxic environment for the denitrification bacteria. Also, in the first stage the TN removal in cMBR was not distinct because the denitrification needed a rather longer procedure than in nitrification. With the development of the cMBR, the denitrification bacteria of the activated sludge and the TN removal was better than before. The highest TN removal ratios were above $50 \%$.

With different strain dosages, different changes took place in the dMBR. From Fig. 7 we could see $10 \%, 20 \%$, $30 \%, 40 \%$, and $50 \%$ of the dosage to the whole activated sludge, and $60 \%, 74.5 \%, 79 \%$, and $80 \%$ TN removal, respectively. The results indicated that the aerobic denitrification bacteria played a role in denitrification and the TN removal may have increased with the increasing strain dosage, which remained at about $80 \%$ TN removal under $30-50 \%$ dosage.

DO is particularly important regarding ecological indicators for the aerobic denitrification bacteria. Patureau et al. [29] studied the aerobic denitrification strain Microvirgulaaero, and they drew the conclusion that it had no influence on the strains' denitrification efficiency when DO concentrations were below $4.5 \mathrm{mg} / \mathrm{L}$, as denitrification enzyme activity began to rise sharply and

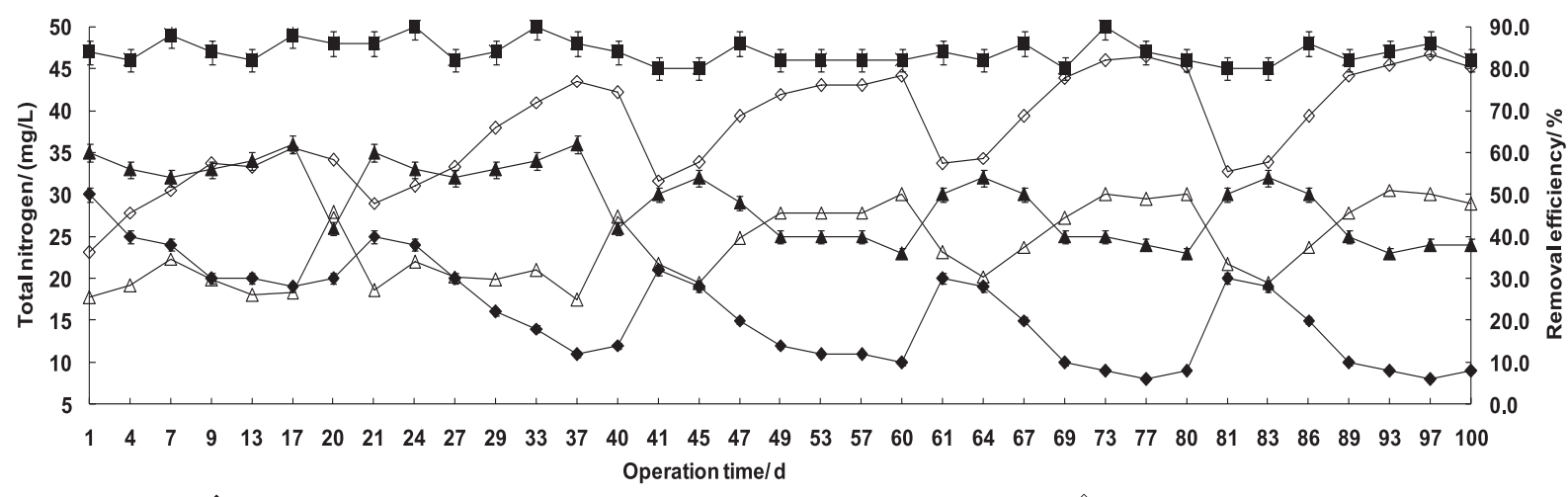

Influent $\diamond$ dMBR effluent $\Delta$ cMBR effluent $\triangle$ cMBR removal efficiency $\diamond$ dMBR removal efficiency

Fig. 7. Variations of total nitrogen removal. 


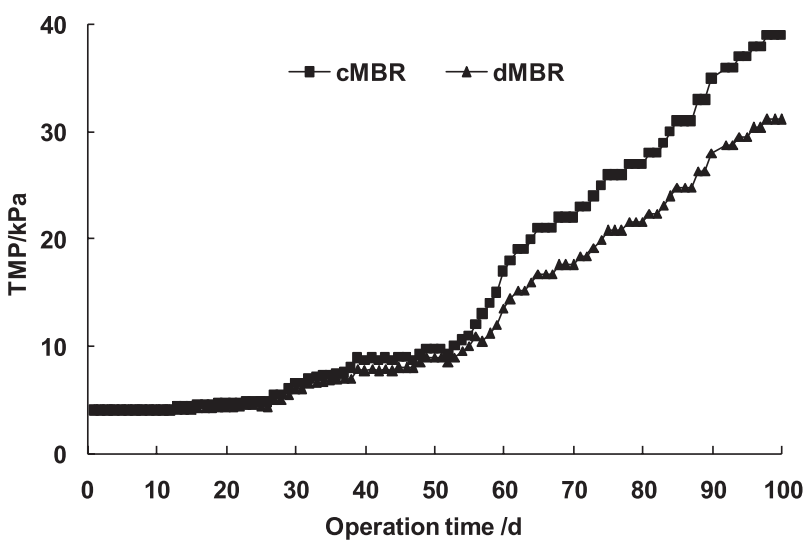

Fig. 8. Variations of TMP in the two MBRs with operation time.

denitrification rates increased greatly. In the MBR tank, although continuous aeration must be given to defect the membrane, DO concentration usually was below $4.5 \mathrm{mg} / \mathrm{L}$ due to the high MLSS concentration. And the ordinary denitrification bacteria could be inhibited under the MBR's DO conditions. dMBR provided a more suitable environment for aerobic denitrification bacteria to compete against other bacteria [12], and good nitrogen removal could be obtained by aerobic denitrification bacteria.

$\mathrm{C} / \mathrm{N}$ ratio is also a very important factor. Previous studies [30-31] researched the effect of carbon sources on SND and the results were always the same - that a higher $\mathrm{C} / \mathrm{N}$ ratio can achieve better SND efficiency. In this study, since the aim was to simulate the actual sewage treatment, the wastewater used in experiments was adjusted to real domestic wastewater, the $\mathrm{C} / \mathrm{N}$ ratio ranged from 6 to 8 all the time. In the latter part of the operation, the carbon source had changed (MBR will produce some substances such as EPS and SMP in supernatant, which could be s carbon source for Strain 1); good nitrogen removal was achieved with the strain dosage increasing in the dMBR and was not obtained in the cMBR. However, because of the difficult degradation of EPS and lack of other carbon sources, it was not easy to achieve better nitrogen removal. Thus, $20-30 \%$ of the dosage is appropriate.

\section{Membrane Fouling}

Membrane fouling was investigated by the TMP changes. Fig. 8 showed the variations of TMP of the two MBRs. As shown clearly in the figure (especially after 50 days operation), the TMP increased more slowly in the dMBR than in cMBR in the experimental period, indicating that the dMBR has a high ability to tolerate the membrane fouling compared with the cMBR. The denitrification strain in the dMBR might play a great role in the resistance of the membrane fouling because the strain in dMBR could adapt to the situation of lacking carbon source and take the $\mathrm{COD}_{\mathrm{Cr}}$ in the supernatant as foodstuff to go on denitrification, which could reduce the membrane filtration pressure.

\section{Conclusions}

1) A kind of high denitrification ability aerobic denitrification strain was screened, which was preliminarily identified as Pseudomonas. And the strain had the ability to use part of EPS and SMP in the MBR supernatant as a carbon resource.

2) The strain was put into the MBR to make a dMBR for municipal wastewater treatment. The TN removal efficiency was as high as $80 \%$ in dMBR, and the TN removal efficiency was $50 \%$ in the control MBR (cMBR). The aerobic denitrification strain in the MBR tank played a main role in removing nitrogen under aerobic conditions. The best strain dosage was $20-30 \%$ with total activated sludge.

3) The dMBR had a better membrane fouling resistant effect from the TMP variations in the two MBRs.

\section{Acknowledgements}

This study was financially supported by the Shaanxi Natural Science Fund (2014JM7256), the Shaanxi Construction Department Science and Technology (project No. 2014-K28), the Special Transport Technological Fund for Western China (2012318361110), the National Natural Science Foundation of China (Nos. 51108437 and 21407012), the Chang'an University Students Innovation Program (201510710073), and the Special Fund for Basic Scientific Research of Central Colleges, Chang'an University (CHD2009JC057, 310829172002, 310829163406). The authors are very grateful to Dr. Yaqian Zhao from University College Dublin and to Dr. Kun Lu from Stanford University for their editing.

\section{References}

1. MATTHEW. P. HOCH, KEVIN S. DILLON, RICHARD B. COFFIN, LUIS A. CIFUENTES. Sensitivity of bacterioplankton nitrogen metabolism to eutrophication in sub-tropical coastal waters of Key West, Florida. Marine Pollution Bulletin. 56 (5), 913, 2007.

2. DOMAGALSKI J., LIN CH., LUO Y., KANG J., WANG S., BROWN L.R., MUNN M.D. Eutrophication study at the Panjiakou-Daheiting Reservoir system, northern Hebei Province, Peopless Republic of China: Chlorophyll-a model and sources of phosphorus and nitrogen. Agricultural Water Management. 94 (1-3), 43, 2007.

3. DJAMBAZOV G., PERICLEOUS K. Modelled atmospheric contribution to nitrogen eutrophication in the English Channel and the southern North Sea. Atmospheric Environment. 102, 191, 2015.

4. ZHANG P., ZHOU Q. Simultaneous nitrification and denitrification in activated sludge system under low oxygen concentration. Frontiers of Environmental Science \& Engineering in China. 1 (1), 49, 2007.

5. PAI S.L., CHONG N.M., CHEN C.H. Potential applications of aerobic denitrifiying bacteria as bioagents in wastewater treatment. Bioresource Technology. 68 (2), 179, 1999. 
6. JOO H.S., HIRAI M., SHODA M. Piggery wastewater treatment using Alcaligenes faecalis strain No. 4 with heterotrophic nitrification and aerobic denitrification. Water Research. 40 (16), 3029, 2006.

7. ZHAO B., HE Y.L., HUANG J., TAYLOR S., HUGHES J. Heterotrophic nitrogen removal by Providencia rettgeri strain YL. Journal of industrial microbiology \& biotechnology. 37 (6), 609, 2010.

8. JOO H.S., HIRAI M., SHODA M. Characteristics of ammonium removal by heterotrophic nitrification-aerobic denitrification by Alcaligenes faecalis No. 4. Journal of Bioscience and Bioengineering. 100 (2), 184, 2005.

9. LARREAA., RAMBO A., FABIYIM. Ten years of industrial and municipal membrane bioreactor (MBR) systems lessons from the field. Water Science and Technology. 70 (2), 279, 2014

10. IVANOVIC I., LEIKNES T.O. Impact of denitrification on the performance of a biofilm-MBR (BF-MBR). Desalination. 283,100, 2011.

11. HU DL, ZHOU Z, SHEN XL, WEI HJ, JIANG LM, LV Y. Effects of alkalinity on membrane bioreactors for reject water treatment: Performance improvement, fouling mitigation and microbial structures. Bioresource Technology. 197, 217, 2015.

12. WANG Z., WU Z., GU G., YU G. Simultaneous nitrogen and phosphor removal in an aerobic submerged membrane bioreactor. Journal of Environment Science of China. 18 (6), 439, 2006.

13. BUISSON H., COTE P., PRADERIE M., PAILLARD H. The use of immersed membranes for upgrading wastewater treatment plants. Water Science and Technology. 37 (9), 89, 1998.

14. LESJEAN B., GNIRSS R., ADAM C. Process configurations adapted to membrane bioreactors for enhanced biological phosphorous and nitrogen removal. Desalination. 149 (1-3), 217, 2002.

15. SAJJAD MUHAMMAD, KIM KWANG SOO. Influence of $\mathrm{Mg}^{2+}$ catalyzed granular sludge on flux sustainability in a sequencing batch membrane bioreactor system. Chemical Engineering Journal. 281, 404, 2015.

16. GUO J.F., LU Y.J. Performance of an enhanced membrane bioreactor (EMBR) by adding aerobic denitrification strains in treating high $\mathrm{NH}_{4}^{+}-\mathrm{N}$ wastewater. In: the 3rd International Conference on Bioinformatics and Biomedical Engineering, Beijing, China,11-13 June, 2009.

17. ZHOU D., MA F., WANG H., DONG S., WANG A. Isolation and denitrification characteristic of an aerobic denitrifier. Journal of Harbin Institute of Technology (New Series). 13 (5) , 535, 2006.

18. GUO J.F., GUAN W.S., XIA S.Q. Membrane fouling of hybrid submerged membrane bioreactor (hMBR) in treating municipal wastewater. Desalination and Water Treatment. 52 (37), 6858, 2014.
19. THE STATE ENVIRONMENTAL PROTECTION ADMINISTRATION. Chinese Water and Wastewater Monitoring Methods, third ed, Chinese Environmental Science Publishing House. Beijing, China, 1997.

20. TAMURA K., STECHER G., PETERSON D., FILIPSKI A., KUMAR S. MEGA6: Molecular Evolutionary Genetics Analysis Version 6.0. Molecular Biology \& Evolution. 30 (12), 2725, 2013

21. SAITOU N., NEI M. The neighbor-joining method: a new method for reconstructing phylogenetic trees. Mol. biol. evol. 4 (6), 406, 1987.

22. VASILIADOU I.A., SIOZIOS S., PAPADAS I.T., BOURTZIS K, PAVLOU S, VAYENAS DV. Kinetics of pure cultures of hydrogen-oxidizing denitrifying bacteria and modeling of the interactions among them in mixed cultures. Biotechnology and Bioengineering. 95 (3), 513, 2006.

23. RAMOS A.F., GÓMEZ M.A., HONTORIA E., GONZÁLEZ-LÓPEZ J. Biological nitrogen and phenol removal from saline industrial wastewater by submerged fixed-film reactor. Journal of Hazardous Materials. 142 (12), 175, 2007.

24. CHEN W.W., LIU J.R., XIE F. Identification of the moderate SRT for reliable operation in MBR. Desalination. 286, 263, 2012.

25. ROSENBERGERA S., LAABS C., LESJEAN B., GNIRSS R., AMY G., JEKEL M., SCHROTTER J.-C. Impact of colloidal and soluble organic material on membrane performance in membrane bioreactors for municipal wastewater treatment. Water Research. 40 (4), 710, 2006.

26. XIA S., GUO J., WANG R. Performance of a Pilot-Scale Submerged Membrane Bioreactor (MBR) in Treating Bathing Wastewater. Bioresource Technology. 99 (15), 6834, 2008.

27. LI X., LIY., LIU H., HUAZ., DU G., CHEN J. Characteristics of aerobic biogranules from membrane bioreactor system. Journal of Membrane Science. 287 (2), 294, 2007.

28. MALAEB L., LE-CLECH P., VROUWENVELDER J.S., AYOUB G.M., SAIKALY P.E. Do biological-based strategies hold promise to biofouling control in MBRs? Water Research. 47 (15), 5447, 2013.

29. PATUREAU D., BERNET N., DELGENÈS J.P, Moletta R. Effect of dissolved oxygen and carbon nitrogen loads on denitrification by anaerobic consortium. Applied Microbiology and Biotechnology, 54 (4), 535, 2000.

30. ZHANG F., LI P., CHEN M.S., WU J.H., ZHU N.W., WU P.X., CHIANG P.C., HU Z.Q. Effect of operational modes on nitrogen removal and nitrous oxide emission in the process of simultaneous nitrification and denitrification. Chemical Engineering Journal. 280, 549, 2015.

31. GOGINA E., GULSHIN I. Simultaneous Denitrification and Nitrification in the Lab-scale Oxidation Ditch with Low C/N Ratio. Procedia Engineering. 117,107, 2015. 